\title{
Subcutaneous Rhytidhysteron Infection: A Case Report from South India with Literature Review
}

\author{
Nagaraja Mudhigeti ${ }^{1}$, Rashmi Patnayak ${ }^{2}$, Usha Kalawat $^{1}$, Spoorthy Rekha C. Yeddula ${ }^{3}$ \\ 1. Department of Microbiology, Sri Venkateswara Institute of Medical Sciences 2. Pathology, IMS \& SUM Hospital 3. \\ Department of Pathology, Sri Venkateswara Institute of Medical Sciences
}

Corresponding author: Rashmi Patnayak, rashmipatnayak2002@yahoo.co.in

\begin{abstract}
Rhytidhysteron is a saprophytic dematiaceous fungus which rarely infects humans. Though virtually all individuals are exposed, very few develop the disease. Only seven human cases are reported till date. The present case is the second case from South India.

A 40-year-old immunocompetent female agricultural worker, presented with a swelling on the dorsum of the right hand. Fine needle aspiration cytology (FNAC) of the swelling revealed short, thick, branched septate fungal hyphae. The isolate was moderately slow growing; grayish white colonies were observed on Sabouraud's Dextrose Agar (SDA) slant. On further incubation, the colonies turned floccose, greyish black and the black pigment was observed on the reverse. Microscopy of lactophenol cotton blue tease mount showed thick, brown septate hyphae without any fruiting bodies. Molecular typing confirmed the isolates as Rhytidhysteron rufulum.
\end{abstract}

Identification of all clinical isolates of nonsporulating fungi to genus level is necessary to identify rare fungi infecting humans.

Categories: Pathology, Infectious Disease, Other

Keywords: molecular typing of rhytidhysteron, rhytidhysteron, dematiaceous fungus, subcutaneous fungal infection

\section{Introduction}

Rhytidhysteron is a saprophytic dematiaceous fungus usually associated with dead or decaying plant tissues [1]. Rhytidhysteron rufulum is a fungus reported which rarely infects humans [2-7]. Rhytidhysteron rufulum is capable of utilising different substrata, therefore, it occupies diverse habitats. The mould is a self-fertile, homothallic species; hence, they are able to maintain sexual reproduction even in the absence of compatible mycelia [8]. The fungus is predominantly seen in tropical and subtropical environments worldwide. This suggests that all individuals are exposed, though very few develop the disease. A thorough literature search revealed only seven human cases reported till date [2-7]. All the reports are from the Indian subcontinent. Here we present one more case of Rhytidhysteron in a healthy adult female. This is the second case from

Received 02/14/2018 Review began 03/12/2018 Review ended 03/30/2018 Published 04/02/2018

() Copyright 2018

Mudhigeti et al. This is an open access article distributed under the terms of the Creative Commons Attribution License CC-BY 3.0., which permits unrestricted use, distribution, and reproduction in any medium, provided the original author and source are credited.
South India. Lower extremity was the site of infection in all other cases whereas in our case the swelling was on the dorsum of the right hand.

\section{Case Presentation}

A 40-year-old female agricultural worker by profession, presented with a swelling on the dorsum of the right hand. The swelling was present on the base of the 3rd phalanx of right hand since last one month. It measured $1 \times 1 \mathrm{~cm}$ and was circular, firm, painless, and freely mobile (Figure 1 ). 


\section{Cureus}

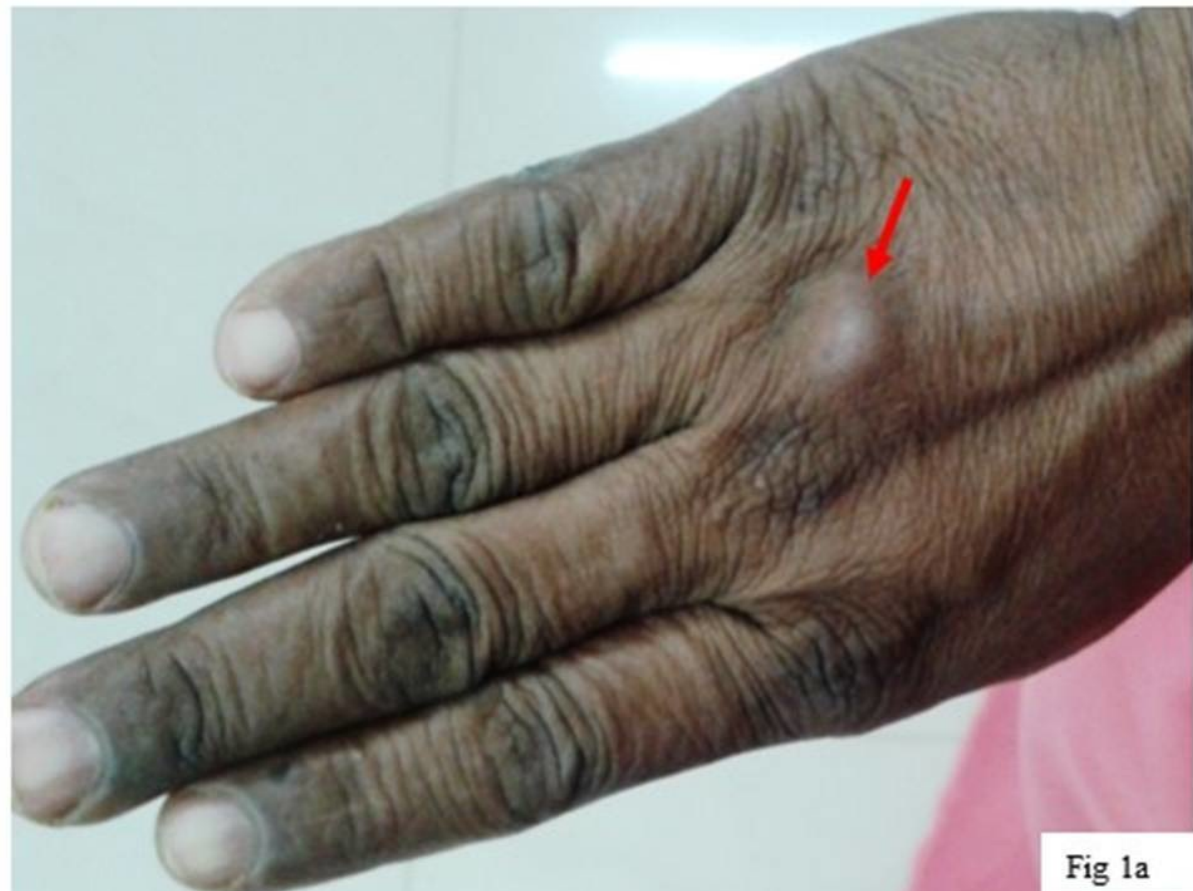

FIGURE 1: Nodule on hand.

A nodule on the base of 3rd phalanx of the right hand.

Initially, it was small but gradually increased to present size within a span of one month. The patient was non-alcoholic, non-smoker and her blood counts and other biochemical parameters were within normal range. Her chest X-ray was normal and she was seronegative for human immunodeficiency virus. She could not recollect any history of injury related to her swelling; however, the possibility of traumatic inoculation could not be ruled out owing to her profession.

Clinically it was diagnosed as ganglion and fine needle aspiration cytology (FNAC) was done. Haematoxylin and Eosin (H\&E) stain of the aspirate revealed short, thick, branched septate fungal hyphae (Figure 2) highlighted on Periodic acid-Schiff (PAS) (Figure 3) and Gomori methenamine silver stain (GMS). The aspirate was also subjected to $10 \%$ potassium hydroxide (KOH) wet mount examination (Figure 4), Gram stain (Figure 5) fungal culture and molecular typing.

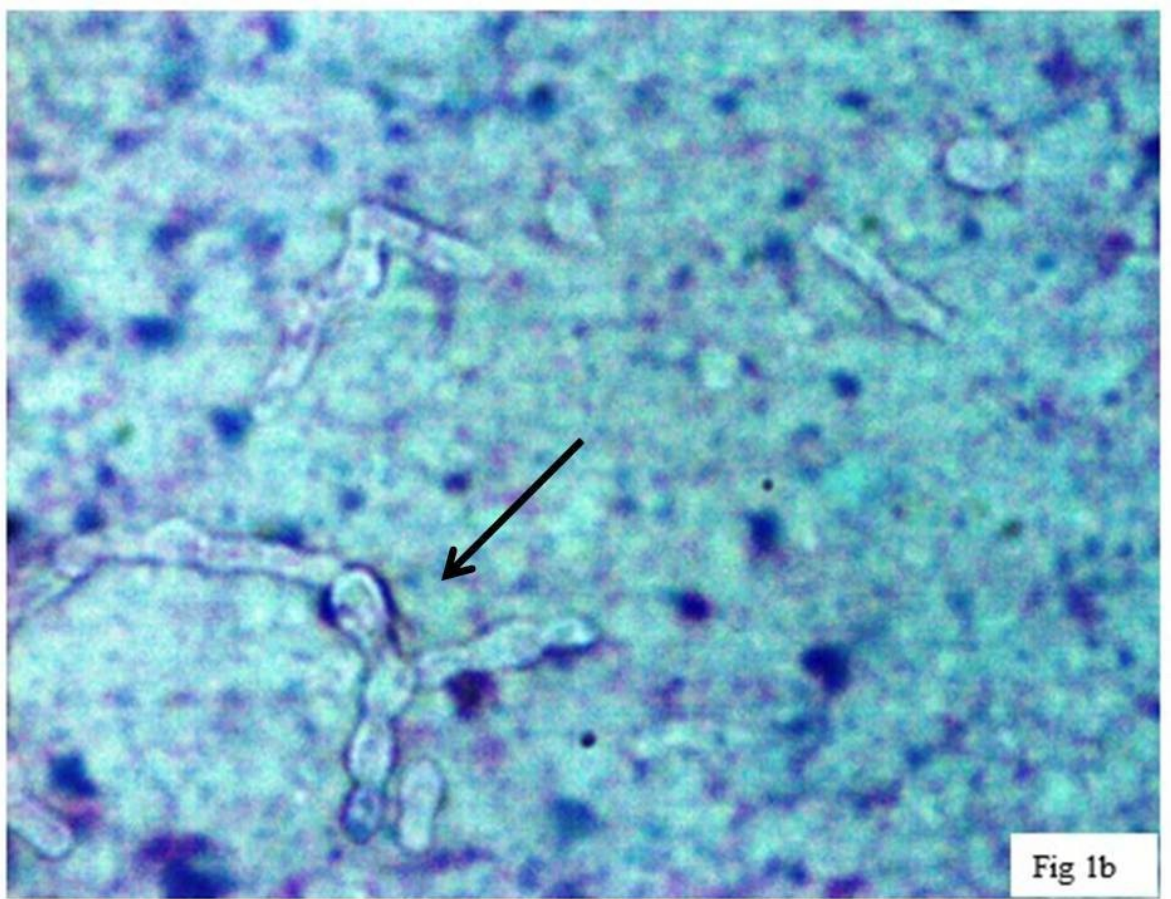




\section{Cureus}

FIGURE 2: Cytology.

Cytology smear showing short, thick, branched fungal hyphae with constrictions and bulbous appearance (Haematoxylin and Eosin x 400).

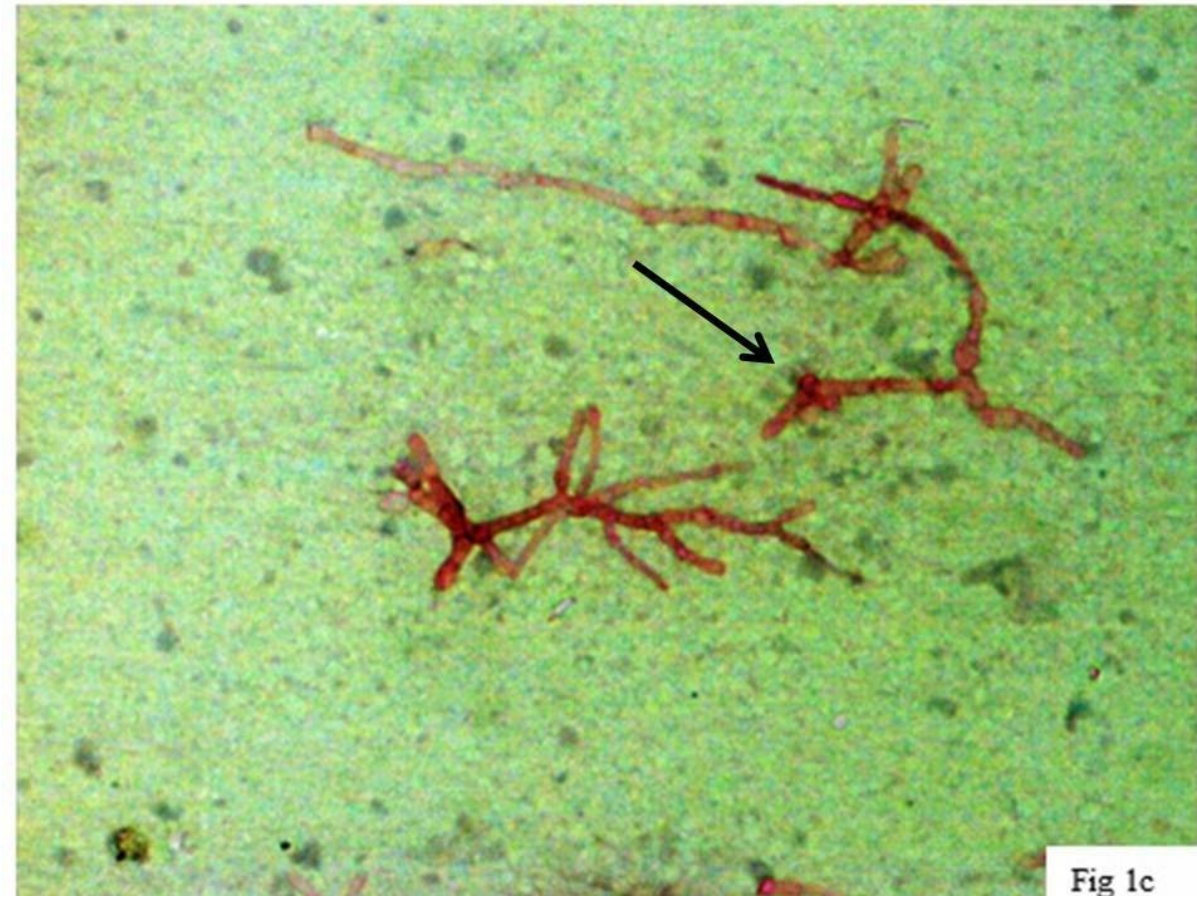

FIGURE 3: Periodic acid-Schiff (PAS) stain.

Fungal hyphae highlighted in PAS stain in a background showing necrotic debris (PAS x 100).

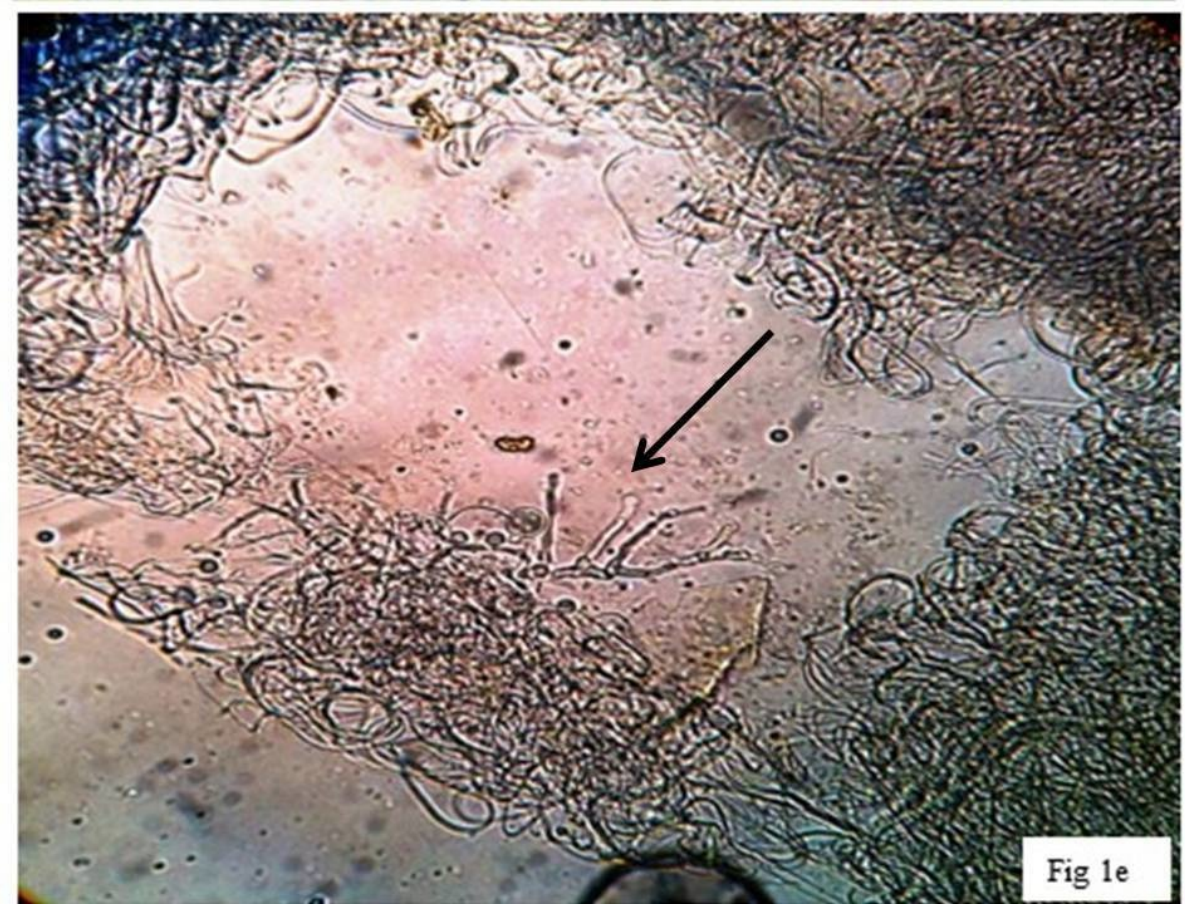




\section{Cureus}

FIGURE 4: KOH preparation of the aspirate showing thin and thickwalled septate hyphae with irregular branching.

$\mathrm{KOH}$ : Potassium hydroxide

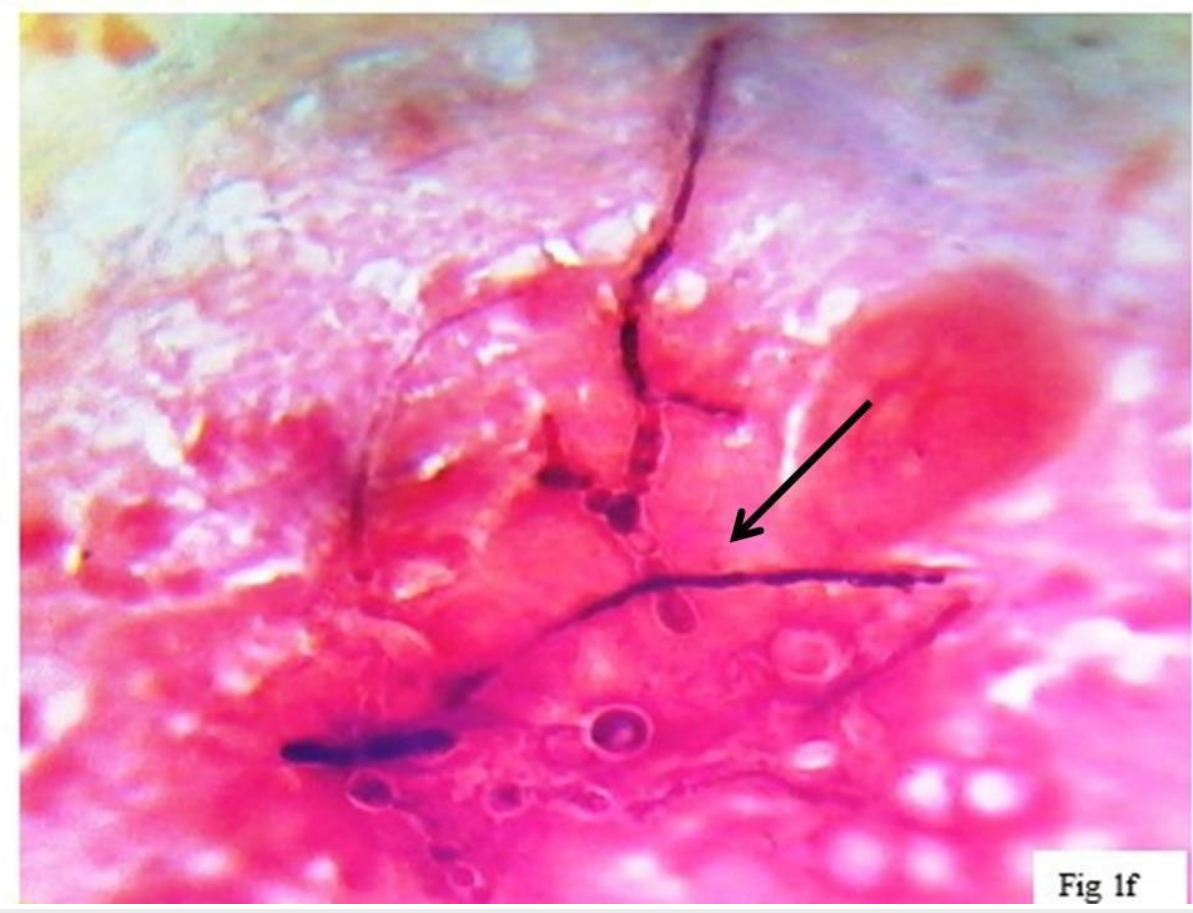

FIGURE 5: Gram-stained smear for routine bacteriology workup demonstrates short, thick, ballooning, septate hyphae with terminal chlamydospore: deeply stained (pink) cytoplasm and unstained (clear zone around hyphae) fungal cell wall is seen $(x 400)$.

The isolate was moderately slow growing; grayish white colonies were observed after one week of incubation at $28^{\circ} \mathrm{C}$ on Sabouraud's Dextrose Agar (SDA) slant. On further incubation, the colonies turned floccose, grayish black and the black pigment was observed on the reverse. Microscopy of lactophenol cotton blue tease mount showed thick, brown septate hyphae without any fruiting bodies.

The isolate failed to sporulate despite repeat attempts to induce sporulation. It was sent to Postgraduate Institute of Medical Research and Education (PGIMER), Chandigarh for molecular analysis. There genomic DNA of the isolate was amplified and sequenced using a set of primers (ITS-1, $5^{\prime}-$

TCCGTAGGTGAACCTTGCGG-3' and ITS-4, 5'-TCCTCCGCTTATTGATATGC-3'), which amplify the internal transcribed spacer (ITS) region of the ribosomal subunit. GenBank basic local alignment search tool (BLAST) was used to (http://www.ncbi.nlm. nih.gov/BLAST/Blast.cgi) perform sequence homology search for species identification. BLAST search confirmed the isolates as Rhytidhysteron rufulum (GenBank accession no. KJ787018). The sequence showed 98-99\% homology to R. rufulum isolates in GenBank (accession no. JX868651.1, KU236376.1, KU236375.1, AM286786.1 and AM711974.1). Case management details are not known as the patient was lost to follow up.

\section{Discussion}

Rhytidhysteron is saprophytic dematiaceous fungi usually associated with dead or decaying plant tissues [1]. No human cases were reported until recently; in 2008, one human case was reported, later in 2014, two cases and in 2016, two more cases were reported. And in 2017, two cases reported were published, one of them was reported from South India [2, 7]. Notably, six cases were reported from North India. Among these, only one case was immunocompromised. Details of these cases are summarised in Table 1. 


\section{Cureus}

\begin{tabular}{|c|c|c|c|c|c|c|c|c|}
\hline \multirow[t]{2}{*}{$\begin{array}{l}\text { S. } \\
\text { No. }\end{array}$} & $\begin{array}{l}\text { Case } \\
\text { reports }\end{array}$ & $\begin{array}{l}\text { Age/ } \\
\text { gender }\end{array}$ & PDF & $\begin{array}{l}\text { Site and type of } \\
\text { lesion/nodule }\end{array}$ & Tissue reaction & Direct microscopy & Management & \\
\hline & & & & & & & Medical & Surgical \\
\hline 1 & $\begin{array}{l}\text { Chowdhary } \\
\text { et al. [2] }\end{array}$ & 50/M & $\begin{array}{l}\text { Renal } \\
\text { transplantation }\end{array}$ & $\begin{array}{l}\text { Noduloulcerative lesions on } \\
\text { left foot and few smaller } \\
\text { lesions over the shin and } \\
\text { thigh }\end{array}$ & $\begin{array}{l}\text { Pseudo- } \\
\text { epitheliomatous } \\
\text { hyperplasia with an } \\
\text { extensive dermal } \\
\text { infiltrate }\end{array}$ & $\begin{array}{l}\text { Thick-walled, spherical, single-celled and } \\
\text { two-celled, muriform sclerotic bodies } \\
\text { with a brownish tinge and thick-walled } \\
\text { chlamydospores. PAS positive. }\end{array}$ & Itraconazole & None \\
\hline 2 & $\begin{array}{l}\text { Mahajan et } \\
\text { al. [3] }\end{array}$ & $72 / \mathrm{M}$ & DM & $\begin{array}{l}\text { Soft, painless, multi- } \\
\text { loculated, non-tender } \\
\text { swelling over the dorsum of } \\
\text { the right foot with erythema } \\
\text { and few sinuses with crusts. }\end{array}$ & $\begin{array}{l}\text { Multiple areas of } \\
\text { neutrophilic abscess } \\
\text { bounded by } \\
\text { epithelioid cells and } \\
\text { foreign body giant } \\
\text { cells }\end{array}$ & $\begin{array}{l}\text { Multiple, broad, septate, irregularly } \\
\text { branched, dematiaceous hyphae, } \\
\text { toruloid hyphae (chains of yeast cells), } \\
\text { and yeast-like cells which were PAS } \\
\text { positive }\end{array}$ & $\begin{array}{l}\text { Itraconazole, } \\
\text { terbinafine } \\
\text { and } \\
\text { liposomal } \\
\text { amphotericin }\end{array}$ & $\begin{array}{l}\text { Swelling } \\
\text { was } \\
\text { surgically } \\
\text { excised }\end{array}$ \\
\hline 3 & $\begin{array}{l}\text { Mishra et } \\
\text { al. [4] }\end{array}$ & $65 / \mathrm{M}$ & None & $\begin{array}{l}\text { Well circumscribed, } \\
\text { indurated, blackish, non- } \\
\text { tender, painless } \\
\text { subcutaneous nodule on } \\
\text { tendoachilles region in the } \\
\text { left foot }\end{array}$ & $\begin{array}{l}\text { Intense neutrophilic } \\
\text { reaction }\end{array}$ & $\begin{array}{l}\text { Thick brown branching septate hyphae. } \\
\text { Hyphae were PAS positive and no } \\
\text { spherical or sclerotic bodies were } \\
\text { present }\end{array}$ & $\begin{array}{l}\text { Terbinafine } \\
\text { and } \\
\text { itraconazole }\end{array}$ & None \\
\hline 4 & $\begin{array}{l}\text { Chander et } \\
\text { al. [5] }\end{array}$ & $45 / M$ & None & $\begin{array}{l}\text { Mobile, non-tender swelling } \\
\text { on thedorsal aspect of the } \\
\text { right foot }\end{array}$ & $\begin{array}{l}\text { Intense neutrophilic } \\
\text { reaction with } \\
\text { lymphocytes, } \\
\text { macrophages and few } \\
\text { septate hyphae }\end{array}$ & $\begin{array}{l}\text { Long, thick, septate, tortuous, dark } \\
\text { brown hyphae and no sclerotic bodies. } \\
\text { Fungal hyphae highlighted on PAS } \\
\text { staining }\end{array}$ & Itraconazole & None \\
\hline 5 & $\begin{array}{l}\text { Chander et } \\
\text { al. [5] }\end{array}$ & $50 / \mathrm{M}$ & None & $\begin{array}{l}\text { Small, soft, non-tender, } \\
\text { movablenodule on the } \\
\text { anterolateral aspect of left } \\
\text { knee }\end{array}$ & & & Itraconazole & $\begin{array}{l}\text { Swelling } \\
\text { was } \\
\text { surgically } \\
\text { excised }\end{array}$ \\
\hline 6 & $\begin{array}{l}\text { Yadav et } \\
\text { al. [6] }\end{array}$ & $54 / \mathrm{M}$ & None & $\begin{array}{l}\text { Well-defined, painless } \\
\text { subcutaneous swelling on } \\
\text { anterior aspect of right leg }\end{array}$ & $\begin{array}{l}\text { Acute and chronic } \\
\text { inflammatory cells and } \\
\text { necrotic background }\end{array}$ & Thick, long septate hyphae & Itraconazole & None \\
\hline 7 & $\begin{array}{l}\text { Tejashree } \\
\text { et al. [7] }\end{array}$ & 59/M & DM & $\begin{array}{l}\text { Painless, large, soft, slowly } \\
\text { progressive, swelling, } \\
\text { noduloulcerative lesion on his } \\
\text { right leg }\end{array}$ & $\begin{array}{l}\text { Mononuclear } \\
\text { inflammatory cell } \\
\text { infiltrates }\end{array}$ & Septate, branching pheoid hyphae & Itraconazole & $\begin{array}{l}\text { Swelling } \\
\text { was } \\
\text { surgically } \\
\text { excised }\end{array}$ \\
\hline 8 & $\begin{array}{l}\text { Present } \\
\text { case }\end{array}$ & $40 / F$ & None & $\begin{array}{l}\text { Small, well circumscribed, } \\
\text { firm, painless, free mobile } \\
\text { swelling on the base of } 3 \text { rd } \\
\text { phalanx of the right hand }\end{array}$ & $\begin{array}{l}\text { Inflammatory } \\
\text { background showing } \\
\text { neutrophils and } \\
\text { necrotic debris }\end{array}$ & $\begin{array}{l}\text { Thick branching septate hyphae with } \\
\text { constrictions and bulbous appearance } \\
\text { which stained positive for PAS and GMS. } \\
\text { Occasional thick-walled chlamydospores } \\
\text { were present }\end{array}$ & NA & NA \\
\hline
\end{tabular}

\section{TABLE 1: Review of published cases of Rhytidhysteron rufulum.}

The nodules were partially retracted in size after two weeks of therapy; however, the patient was expired due to underlying risk factors (renal transplantation, abdominal tuberculosis and multi-organ failure).

PDF: Predisposing factors; DM: Diabetes mellitus; NA: Not available; GMS: Gomori methenamine silver stain; PAS: Periodic acid-Schiff.

Rhytidhysteron rufulum is capable of utilising different substrata and occupying diverse habitats. It is seen in tropical and subtropical environments worldwide. Rhytidhysteron infects mainly through traumatic inoculation, therefore, occupation seems to play an important role in the incidence of this disease [4]. The majority of the lesions are observed on extremities of outdoor workers, mainly male rural workers. It produces primary transcutaneous lesion or swelling following several days or months of traumatic inoculation [2-7]. The size of the lesion/nodule and severity of the disease depends on the patient's immune status and underlying risk factors such as diabetes [2-7]. 
To date, only seven human cases are reported in the literature, and very little is known about its pathogenicity of the mould on human cells [2-7]. All the cases reported so far have lesion in the lower extremity in contrast to the present case which was a hand swelling.

Rhytidhysteron rufulum has a putative orthologous gene set that code for dothistromin, a mycotoxin. Dothistromin is found to lyse human red blood cells (RBCs) in vitro [9]. This may explain the pathogenic potential of Rhytidhysteron on human cells.

Presentation of patients with Rhytidhysteron infection may vary from single nodule at the site of traumatic inoculation to multiple spreading noduloulcerative lesions: sometimes the overlying skin may have few sinuses with crusts [2-6]. Direct microscopy of specimens reveals thick-walled, spherical, single-celled/twocelled or brownish muriform sclerotic bodies. Sometimes thick brown hyphae with or without budding fungal bodies can be seen [2-7].

The fungus grows on any routine culture media used for isolation of fungi. Sabouraud's dextrose agar supplemented with chloramphenicol or Potato Dextrose Agar is most commonly used media to isolate fungus from cutaneous specimens. Colonies of Rhytidhysteron appear as velvety light grey-white which floccose after one week of incubation at both $25^{\circ} \mathrm{C}$ and $37^{\circ} \mathrm{C}$ (culture tubes can be incubated at $28^{\circ} \mathrm{C}$ if only one tube is inoculated). The reverse of the colonies is usually brown to black. Colonies develop dark (greyish black) pigmentation on further incubation (up to four weeks) [2-7].

Lactophenol Cotton Blue wet mount of this fungus demonstrates only septate, irregularly branched, smooth-walled, sterile (vegetative) dematiaceous hyphae without any spores. Sometimes toruloid hyphae and thick-walled terminal chlamydospores can be seen. Several workers have tried to induce sporulation using different culture media including potato dextrose agar, rice agar, cornmeal agar, malt extract agar and water agar but never succeeded like the present case [2-7]. Since it is a non-sporulating mould, it is difficult to identify by the conventional methods.

Therefore, molecular characterization is an indispensable method for identification of this black mould. Molecular characterization involves amplification PCR (Polymerase chain reaction) of known conserved genes with enough sequence variation followed by sequencing and BLAST searching against GenBank or other databases for sequence homology [10]. Many authors including us have successfully identified their isolates using ITS1 and ITS4 primer set 98-100\% homology with Genbank Rhytidhysteron rufulum sequences [4-7].

Patients with mild to moderate infection or uninoculated lesion respond well with oral itraconazole with or without terbinafine therapy. In contrast, patients with severe infection or widespread lesions required surgical intervention followed by prolonged combination therapy. Usually, large and multiloculated lesions require an intralesional amphotericin in addition to combination therapy [2-7]. Additional data is required to understand therapeutic options and outcome of rare Rhytidhysteron infection in humans.

\section{Conclusions}

As Rhytidhysteron fails to sporulate in artificial culture media, PCR amplification ITS1-ITS4 genes followed by sequence analysis is the method of choice for diagnosis available at present. Identification of all clinical isolates of nonsporulating fungi to genus level is desirable to identify new/emerging fungi.

\section{Additional Information}

\section{Disclosures}

Human subjects: Consent was obtained by all participants in this study. Conflicts of interest: In compliance with the ICMJE uniform disclosure form, all authors declare the following: Payment/services info: All authors have declared that no financial support was received from any organization for the submitted work. Financial relationships: All authors have declared that they have no financial relationships at present or within the previous three years with any organizations that might have an interest in the submitted work. Other relationships: All authors have declared that there are no other relationships or activities that could appear to have influenced the submitted work.

\section{Acknowledgements}

Authors are thankful to Dr Arunaloke Chakrabarti, Professor Department of Medical Microbiology, and Centre for Advanced Research in Medical Mycology, Post Graduate Institute of Medical Education and Research, Chandigarh, India for confirming our isolate.

\section{References}

1. Ohm RA, Feau N, Henrissat B, et al.: Diverse lifestyles and strategies of plant pathogenesis encoded in the genomes of eighteen Dothideomycetes fungi. PLoS Pathog. 2012, 8:1003037. 10.1371/journal.ppat.1003037 


\section{Cureus}

2. Chowdhary A, Guarro J, Randhawa HS, et al.: A rare case of chromoblastomycosis in a renal transplant recipient caused by a non-sporulating species of Rhytidhysteron. Med Mycol. 2008, 46:163-166. 10.1080/13693780701630420

3. Mahajan VK, Sharma V, Prabha N, et al.: A rare case of subcutaneous phaeohyphomycosis caused by a Rhytidhysteron species: a clinico-therapeutic experience. Int J Dermatol. 2014, 53:1485-1489. 10.1111/ijd.12529

4. Mishra K, Das S, Goyal S, et al.: Subcutaneous mycoses caused by Rhytidhysteron species in an immunocompetent patient. Med Mycol Case Rep. 2014, 5:32-34. 10.1016/j.mmcr.2014.07.002

5. Chander J, Singla N, Kundu R, Handa U, Chowdhary A: Phaeohyphomycosis caused by Rhytidhysteron rufulum and review of literature. Mycopathologia. 2017, 182:403-407. 10.1007/s11046-016-0064-X

6. Yadav S, Agarwal R, Chander J, Chowdhary A: A rare case report of subcutaneous mycoses by Rhytidhysteron rufulum. Int J Med Res Health Sci. 2017, 6:12-15. http://www.ijmrhs.com/medicalresearch/a-rare-case-report-of-subcutaneous-mycoses-by-rhytidhysteron-rufulum.pdf

7. Tejashree A, Suchetha C, Visakha K, Karthik KM: A rare case of subcutaneous phaeohyphomycosis caused by Rhytidhysteron rufulum. Indian J Microbiol Res. 2017, 4:468-470. 10.18231/2394-5478.2017.0104

8. Murillo C, Albertazzi FJ, Carranza J, Lumbsch HT, Tamayo G: Molecular data indicate that Rhytidhysteron rufulum (ascomycetes, Patellariales) in Costa Rica consists of four distinct lineages corroborated by morphological and chemical characters. Mycol Res. 2009, 113:405-416. 10.1016/j.mycres.2008.09.003

9. Kabir MS, Ganley RJ, Bradshaw RE: Dothistromin toxin is a virulence factor in dothistroma needle blight of pines. Plant Pathol. 2015, 64:225-234. 10.1111/ppa.12229

10. White TJ, Bruns T, Lee S, Taylor J: Amplification and direct sequencing of fungal ribosomal RNA genes for phylogenetics. PCR Protocols: A Guide to Methods and Applications. Innis MA, Gelfand DH, Sninsky JJ, White TJ (ed): Academic Press, Orlando, Florida; 1990. 315-322. 